\title{
Characterization of organic solar cells using semiconducting polymers with different bandgaps
}

https://doi.org/10.1515/polyeng-2019-0052

Received February 11, 2019; accepted May 17, 2019; previously published online June 27, 2019

\begin{abstract}
Polymer-based organic solar cells are of great interest as they can be produced with low-cost techniques and also have many interesting features such as flexibility, graded transparency, easy integration, and lightness. However, conventional wide bandgap polymers used for the light-absorbing layer significantly affect the power conversion efficiency of organic solar cells because they collect sunlight in a given spectrum range and due to their limited stability. Therefore, in this study, polymers with different bandgaps were used, which could allow for the production of more stable and efficient organic solar cells: P3HT as the wide bandgap polymer, and PTB7 and PCDTBT as low bandgap polymers. These polymers with different bandgaps were combined with PCBM to obtain increased efficiency and optimum photoactive layer in the organic solar cell. The obtained devices were characterized by measuring optical, photoelectrical, and morphological properties. Solar cells using the PTB7 and PCDTBT polymers had more rough surfaces than the reference cell using P3HT. The use of low-bandgap polymers improved $I_{\text {sc }}$ significantly, and when combined with P3HT, a higher $V_{\text {oc }}$ was obtained.
\end{abstract}

Keywords: low bandgap; organic solar cell; P3HT; PCBM; PCDTBT; PTB7; semiconducting polymer.

\section{Introduction}

Production of electrical energy from renewable resources can be the most efficient and beneficial way to control environmental problems related to global warming caused

\footnotetext{
*Corresponding author: Ayse Celik Bedeloglu, Department of Fiber and Polymer Engineering, Bursa Technical University, Mimar Sinan Campus, E Blok Yıldırım, Bursa 16190, Turkey, e-mail: ayse.bedeloglu@btu.edu.tr Ismail Borazan: Department of Textile Engineering, Bartin University, Bartin, Turkey. https://orcid.org/0000-0001-7726-4045 Yasin Altin: Department of Fiber and Polymer Engineering, Bursa Technical University, Mimar Sinan Campus, E Blok Yıldırım, Bursa 16190, Turkey. https://orcid.org/0000-0002-8554-3025 Ali Demir: Faculty of Textile Technologies and Design, Istanbul Technical University, Istanbul, Turkey
}

by use of fossil fuels [1]. A solar cell which generates electricity from photons of the sun via photovoltaic effect is an interesting device since it uses abundant, clean, and renewable solar energy. To obtain clean and renewable energy, the cumulative photovoltaic technology capacity in the world exceeded $415 \mathrm{GWp}$ in 2017 [2]. Unlike other solar cell technologies using complicated and costly processes, in the last years, organic solar cells have attracted great attention due to the advantages of inexpensive production; lightweight and flexible substrates and materials; easy, scalable, and high speed processes; and roll-to-roll and solution processing, which are mainly caused by semiconducting polymers [3].

The optimum mixture of conjugated polymers as the donor and the fullerene as acceptor plays a crucial role since an ultrafast photoinduced charge transfer should take place in the polymer-based organic solar cells [4]. In an organic solar cell, the following steps happen: transferring charges at the donor-acceptor interface, transporting charges, and collecting charges by related electrodes [5]. The power conversion efficiency (PCE) of the organic solar cells is affected by the structure and ratio of the photoactive materials (fullerenes, semiconducting polymers etc.), the morphology of the film etc. [6, 7]. The semiconducting polymers with their outstanding properties including flexibility, low cost, easy processing, and tunable optical, electronic and chemical features are widely used in solar cells compared to other inorganic materials $[8,9]$. The mismatch between the absorption spectrum of the photoactive layer and the solar spectrum is a limiting factor for efficiency. Besides, the glass or polymer substrates and front electrodes absorb photons before reaching the photoactive layer in some part of the spectrum $(<400 \mathrm{~nm})$. While the lower wavelengths (in the range of $280-400 \mathrm{~nm}$ ) of the spectrum absorb approximately $1.4 \%$ of the total light, higher wavelengths (i.e. $1000 \mathrm{~nm}$ ) by decreasing the bandgap may absorb over $50 \%$ of the light by providing an increase in current, theoretically [10].

The semiconducting polymers with different bandgap play a role in determining the photocurrent generation. Low bandgap polymers having bandgap smaller than $1.6 \mathrm{eV}$ can absorb light in the near-infrared (NIR) region by increasing short-circuit current density $\left.U_{S C}\right)$ resulting in higher PCE $[8,9]$. Therefore, the bandgap of the semiconducting polymers used has crucial importance for enhancing PCE. Besides, since a limitation related to the use of low bandgap polymers is the low open-circuit voltage $\left(V_{o c}\right)$ 
obtained, an optimum blend should be applied in the solar cell. Although many studies have been done with conventional wide bandgap polymers, intensive studies using new active layer materials about an improvement of stability and PCE of organic solar cells are still going on [11]. In the last years, researchers have focused on low bandgap polymers to improve organic solar cell efficiency and stability, since the synthesis and use of several new low bandgap polymers gave very promising results in polymerbased organic solar cells [12-23]. There are also a number of studies dealing with the improvement of power conversion efficiencies of organic solar cells [24-29].

In this study, the effect of semiconducting polymers with different bandgaps was investigated in a polymer-based organic solar cell. Therefore, five different blends were made by using poly(3-hexylthiophene-2,5-diyl) (P3HT), poly[[4,8-bis[(2-ethylhexyl)oxy] benzo[1,2-b:4,5-b']dithiophene-2,6-diyl][3-fluoro-2-[(2ethylhexyl)carbonyl]thieno[3,4-b]thiophenediyl]] (PTB7), poly[N-9'-heptadecanyl-2,7-carbazole-alt-5,5-(4',7'-di-2thienyl-2', $1^{\prime}, 3^{\prime}$-benzothiadiazole)], poly[[9-(1-octylnonyl)9H-carbazole-2,7-diyl]-2,5-thiophenediyl-2,1,3-benzothiadiazole-4,7-diyl-2,5-thiophenediyl] (PCDTBT) and [6,6]-phenyl $\mathrm{C}_{61}$ butyric acid methyl ester $\left(\mathrm{PC}_{61} \mathrm{BM}\right)$. In order to understand the influence of materials, the optical, morphological and photoelectrical characterizations were performed.

\section{Materials and methods}

\subsection{Materials}

Highly conductive poly(3,4-ethylenedioxythiophene)poly(styrenesulfonate) (PEDOT:PSS) (Clevious PH 1000) solution was used as a buffer layer. Five percent dimethylsulfoxide and 0.1\% Triton X-100 (from Sigma Aldrich) by volume were mixed with PEDOT:PSS solution to enhance the conductivity and wetting properties, respectively. Chemical structures of P3HT (regioregular, average $\mathrm{M}_{\mathrm{n}}$ : 54,000-75,000, electronic grade, 99.995\%), PTB7 (average $M_{w}$ 80,000-200,000, PDI 53.0), PEDOT:PSS, PCDTBT (average $\mathrm{M}_{\mathrm{w}:}$ 100,000-140,000) and $\mathrm{PC}_{61} \mathrm{BM}$ are given in Figure 1A-E, respectively.

The photoactive material solutions were prepared using blends of P3HT:PC ${ }_{61}$ BM, P3HT/PTB7/PCDTBT:PC ${ }_{61}$ BM, P3HT/PTB7:PC ${ }_{61} \mathrm{BM}$, P3HT/PCDTBT:PC ${ }_{61} \mathrm{BM}$ and PTB7/ PCDTBT:PC ${ }_{61} \mathrm{BM}$ separately. A blend of polymers with a weight ratio of 1:1, 0.5/0.25/0.25:1, 0.5/0.5:1, 0.5/0.5:1, and 0.5/0.5:1, respectively. P3HT:PC61BM, Р3HT/ PTB7/PCDTBT:PC 61 BM, P3HT/PTB7:PC ${ }_{61} \mathrm{BM}, \quad$ P3HT/ PCDTBT:PC ${ }_{61} \mathrm{BM}$ and PTB7/PCDTBT:PC ${ }_{61} \mathrm{BM}$, in $20 \mathrm{mg} /$ $\mathrm{ml}$ chlorobenzene solution was stirred for $24 \mathrm{~h}$ at room temperature.

\subsection{Photovoltaic device fabrication}

In this study, five different types of solar cells were produced. One of them as reference cell had P3HT: $\mathrm{PC}_{61} \mathrm{BM}$ wide bandgap polymer as a photoactive layer. The polymer-based organic solar cells were prepared by the following procedure: conventional indium tin oxide (ITO, or tin-doped indium oxide)-coated glasses (Teknoma, İzmir) with a sheet resistance (less than $10 \Omega / \mathrm{cm}^{2}$ ) were cut in $25^{\star} 25 \mathrm{~mm}^{2}$ to be used in experimental studies. For etching, some part of the ITO layer from the glass substrate, an acid mixture containing hydrochloric acid $(\mathrm{HCl})$, nitric acid $\left(\mathrm{HNO}_{3}\right)$, and water $\left(\mathrm{H}_{2} \mathrm{O}\right)$, was applied for $30 \mathrm{~min}$. After the etching process, samples were washed with water,
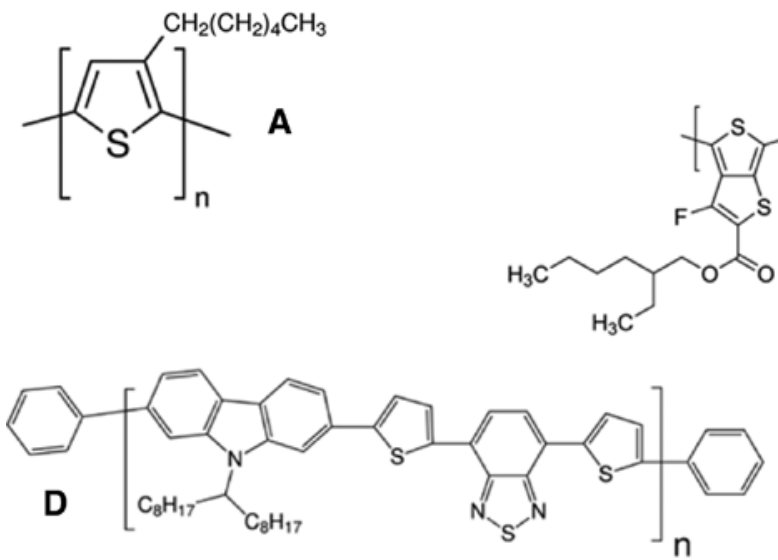<smiles>CCCCC(CC)CC</smiles>

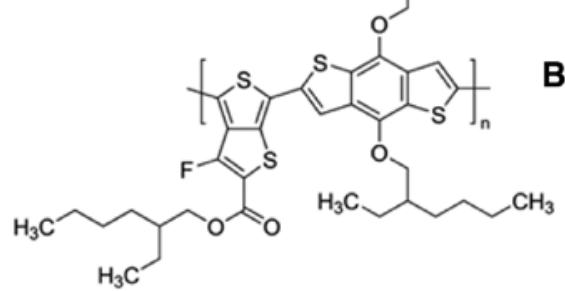

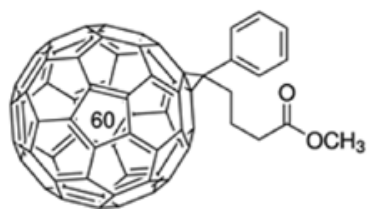

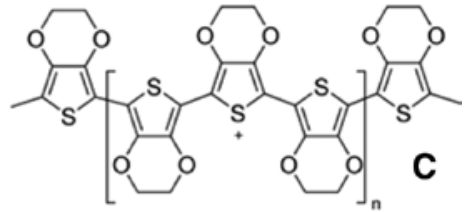

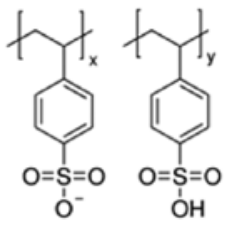

E

Figure 1: Chemical structures of (A) P3HT, (B) PTB7, (C) PEDOT:PSS, (D) PCDTBT, and (E) PC ${ }_{61} B M$. 
acetone, isopropanol, ethanol, and methanol in an ultrasonic bath for $15 \mathrm{~min}$, respectively. Later, an aqueous solution of highly conductive PEDOT:PSS mixture was coated (2000 rpm and $60 \mathrm{~s}$ ) onto pre-cleaned ITO-coated glass substrates. Then, the samples were completely dried for $5 \mathrm{~min}$ at $100^{\circ} \mathrm{C}$ on a hot plate.

Five types of photoactive material mixtures were prepared as mentioned before. The wide bandgap P3HT, low bandgap PTB7, and PCDTBT worked as the electron donating polymers and $\mathrm{PC}_{61} \mathrm{BM}$ worked as electron-accepting material in the blend. The light-absorbing layer $(-60 \mathrm{~nm})$ was deposited by spin-coating technique on the top of PEDOT:PSS covered on top of the ITO-coated substrates for $60 \mathrm{~s}$ at $2000 \mathrm{rpm}$. Subsequently, $100 \mathrm{~nm}$ aluminum (Al) contact was evaporated thermally under vacuum $\left(10^{-6}\right.$ mbar) on top of the photoactive layers as a top electrode. The active area was $10 \mathrm{~mm}^{2}$.

In Figure $2 \mathrm{~A}$ and $\mathrm{B}$, obtained organic solar cells (P3HT:PCBM-PTB7:PCDTBT:PCBM) and the schematic demonstration of produced organic solar cells are shown, respectively. Subsequently, silver paint was put onto the electrodes of the solar cells to take better conductivity from the contacts.

\subsection{Characterization}

The photovoltaic PCE of a solar cell is calculated by the following formula [30]:

$$
\begin{aligned}
& \eta=\frac{V_{\mathrm{oc}} * I_{\mathrm{sc}} * F F}{P_{\text {in }}} \\
& F F=\frac{V_{\mathrm{mpp}} * I_{\mathrm{mpp}}}{I_{\mathrm{sc}} * V_{\mathrm{oc}}}
\end{aligned}
$$

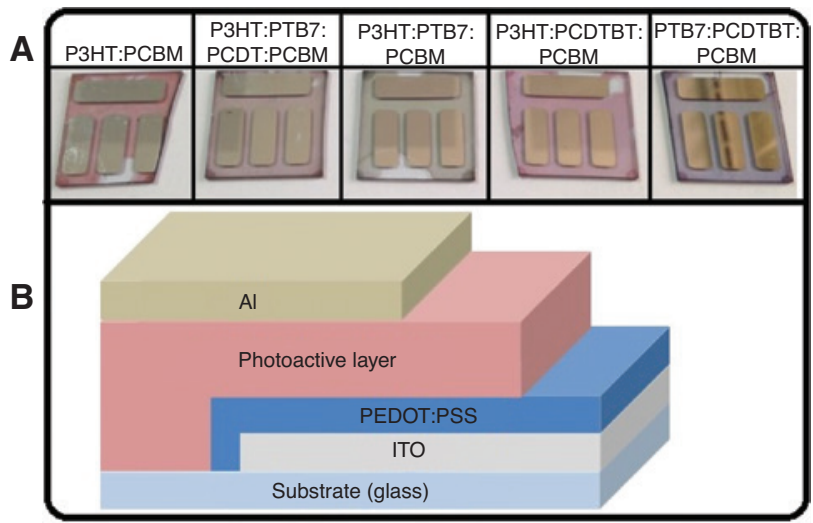

Figure 2: (A) Images of the fabricated organic solar cells with the composition of the photoactive layers. (B) Schematic drawing of the produced polymer-based organic solar cell on ITO-coated glass substrate. where $\eta$ is the PCE, $V_{\mathrm{oc}}$ is the open circuit voltage, $I_{\mathrm{sc}}$ is the short circuit current, $F F$ is the fill factor, and $P_{\text {in }}$ is the incident light power density. This light intensity is standardized at $1000 \mathrm{~W} / \mathrm{m}^{2}$ according to AM 1.5 spectrum. $I_{\text {mpp }}$ and $V_{\text {mpp }}$ are the current and voltage at the maximum power point.

The IV data of the fabricated solar cells were taken from Keithley 2400 source meter via Labview program by illuminating the cells from the glass side with a Lot-Oriel Solar simulator. The absorbance of the photoactive layers was measured via a UV-vis NIR Spectrophotometer (Shimadzu UV-3600) between $400 \mathrm{~nm}$ and $700 \mathrm{~nm}$ (with an increment of $5 \mathrm{~nm}$ ). Morphological features of the thin films produced were determined using the AFM (atomic force microscope) device. Tapping method was used for AFM analysis, and scans were performed in $5 \times 5$ and $10 \times 10 \mu \mathrm{m}^{2}$ area.

\section{Results and discussion}

\subsection{Optical results}

While the maximum absorption peak of P3HT is located at about $550 \mathrm{~nm}$, the absorption range of regioregular P3HT extends approximately from $400 \mathrm{~nm}$ to $650 \mathrm{~nm}$ which is in the visible range of the spectrum. On the other hand, PCBM absorbs light in the UV range (at $350 \mathrm{~nm}$ ). Therefore, some of the photons (above $\sim 650 \mathrm{~nm}$ ) cannot be absorbed in the whole spectrum [31, 32]. Besides, PTB7 as the thin film itself shows maximum absorption at $680 \mathrm{~nm}$ covering over the range of 550-700 [33], and PCDTBT shows maximum absorption at $576 \mathrm{~nm}$ [34]. The influence of different absorption trends of semiconducting polymers is also seen in Figure 3. P3HT:PCBM shows

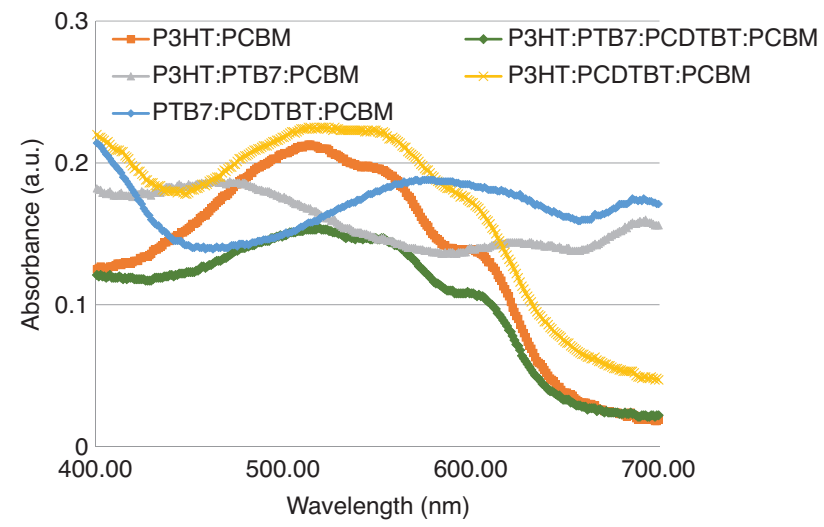

Figure 3: Absorbance (a.u.) spectra of photoactive polymer films of produced solar cells. 
the typical absorption peaks including P3HT and PCBM, when Figure 3 is considered. While photoactive polymer films of P3HT:PCBM, P3HT:PTB7:PCDTBT:PCBM and P3HT:PCDTBT:PCBM show similar absorption curves which decrease after $600 \mathrm{~nm}$, P3HT:PCDTBT:PCBM shows higher and broader absorption peak than P3HT:PCBM and P3HT:PTB7:PCDTBT:PCBM in the visible region. Besides, after $600 \mathrm{~nm}$, photoactive polymer films of P3HT:PTB7:PCBM and PTB7:PCDTBT:PCBM have similar trends which continue without a decrease in absorption curves as well as absorbing some part of the light in the visible region, too.

\subsection{Photoelectrical results}

Photoelectrical results of organic solar cells as $I_{\mathrm{sc}}(\mathrm{mA} /$ $\left.\mathrm{cm}^{2}\right), V_{\text {oc }}(\mathrm{mV}), F F(\%)$, and $\eta(\%)$ are presented in Table 1. Besides, linear curves of current density-voltage characteristics of the solar cells under $100 \mathrm{~mW} / \mathrm{cm}^{2}$ illumination (AM1.5) are given in Figure 4. As it is known, PCBM with $\sim 2.4 \mathrm{eV}$ (HOMO $6.1 \mathrm{eV}$ and LUMO $3.7 \mathrm{eV}$ ) is an n-type semiconductor with an electron mobility of $0.21 \mathrm{~cm}^{2} /$ Vs. P-type semiconducting polymers, P3HT with $\sim 2 \mathrm{eV}$ bandgap (HOMO $5 \mathrm{eV}$ and LUMO $3 \mathrm{eV}$ ) [35], PCDTBT with $\sim 1.9 \mathrm{eV}$ bandgap (HOMO $5.5 \mathrm{eV}$ and LUMO $3.6 \mathrm{eV}$ ) [28], and PTB7 with $~ 1.84 \mathrm{eV}$ bandgap (HOMO 5.15 and LUMO 3.31) [36] have the following hole mobilities:

Table 1: Photoelectrical results of the produced organic solar cells.

\begin{tabular}{lrrrr}
\hline Photoactive layer composition & $\boldsymbol{l}_{\mathbf{s c}}\left(\mathbf{m A} / \mathbf{c m}^{2}\right)$ & $\boldsymbol{V}_{\text {oc }}(\mathbf{m V})$ & $\boldsymbol{F} \boldsymbol{F}(\%)$ & $\boldsymbol{\eta}(\%)$ \\
\hline P3HT:PCBM & 7.37 & 649 & 39 & 1.88 \\
P3HT:PTB7:PCDTBT:PCBM & 5.99 & 758 & 27 & 1.21 \\
P3HT:PTB7:PCBM & 5.98 & 782 & 30 & 1.40 \\
P3HT:PCDTBT:PCBM & 7.43 & 746 & 31 & 1.72 \\
PTB7:PCDTBT:PCBM & 8.84 & 649 & 31 & 1.77 \\
\hline
\end{tabular}

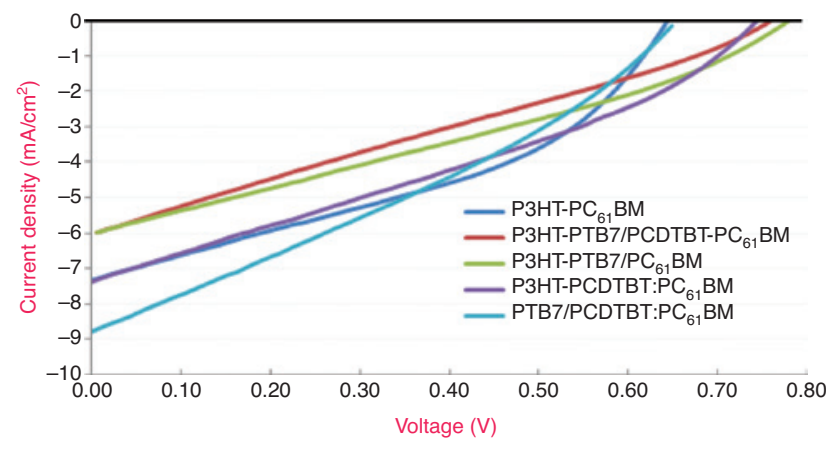

Figure 4: Linear curves of current density-voltage characteristics of prepared devices under $100 \mathrm{~mW} / \mathrm{cm}^{2}$ illumination (AM1.5).
$10^{-4}-10^{-1} \mathrm{~cm}^{2} / \mathrm{V} \times \mathrm{s}, 6 \times 10^{-5} \mathrm{~cm}^{2} / \mathrm{V} \times \mathrm{s}$, and $1 \times 10^{-3} \mathrm{~cm}^{2} / \mathrm{V} \times \mathrm{s}$ (as neat film) and $2 \times 10^{-4} \mathrm{~cm}^{2} / \mathrm{V} \times \mathrm{s}$ (in blend) [37], respectively. Photoelectrical results of solar cells were influenced from different bandgaps of these semiconducting polymers. The maximum $I_{\mathrm{sc}}$ as $8.84 \mathrm{~mA} / \mathrm{cm}^{2}$ was obtained from PTB7:PCDTBT:PCBM, PTB7/PCDTBT:PC ${ }_{61} \mathrm{BM}$ (0.5:0.5:1 w/w/w). Use of low bandgap polymers also slightly improved the $I_{\mathrm{sc}}$ in P3HT:PCDTBT:PCBM. On the other hand, while P3HT:PTB7:PCBM gave the highest $V_{\text {oc }}$ of $782 \mathrm{mV}$, P3HT:PCBM and PTB7:PCDTBT:PCBM showed the lowest $V_{\text {oc }}$ as $649 \mathrm{mV}$. As mentioned in the previous studies, while the use of completely low bandgap polymer in the organic solar cell made a successful increase in $I_{\text {sc }}$, moderate $V_{\text {oc }}$ (PTB7:PCDTBT:PCBM) was obtained [11]. While combining the low bandgap polymers with a wide bandgap polymer, P3HT, brought about an improvement in solar cells (including P3HT:PTB7:PCDTBT:PCBM, P3HT:PTB7:PCBM and P3HT:PCDTBT:PCBM active layers), the use of low bandgap polymers decreased the fill factor shown in Table 1 and Figure 4. Therefore, lower power conversion efficiencies were obtained from devices based on P3HT:PTB7:PCDTBT:PCBM, P3HT:PTB7:PCBM, P3HT:PCDTBT:PCBM, and PTB7:PCDTBT:PCBM.

The AFM images of the five blends are given in Figure 5. According to AFM images, it can be seen that the surface roughness of polymer films of P3HT:PCBM and P3HT:PTB7:PCDTBT:PCBM due to homogenous blend are below $12 \mathrm{~nm}$. However, it can be clearly seen that PCDTBT and PTB7 show very rough morphology and have big grain size in their blends. Low film thickness $(60 \mathrm{~nm})$ and the roughness of photoactive layers supported by the AFM images increased the internal resistances resulting in low $F F$. As can be seen from Figure 5, P3HT:PCDTBT:PCBM has rougher surface than P3HT:PTB7:PCBM and PTB7:PCDTBT:PCBM. Generally, since smooth surface would ensure better contact between active layer and electrodes, the lower surface roughness is required in most of the solar cells [30]. Therefore, by the use of P3HT, a flatter surface resulting in a better contact and an improved charge transfer at the active layer-electrode interfaces was obtained.

\section{Conclusions}

In this paper, semiconducting polymers with different bandgaps were used to produce organic solar cells. In terms of optical properties, while P3HT:PCDTBT:PCBM showed higher and broader absorption until $650 \mathrm{~nm}$, above $600 \mathrm{~nm}$, linear absorption curves were obtained 

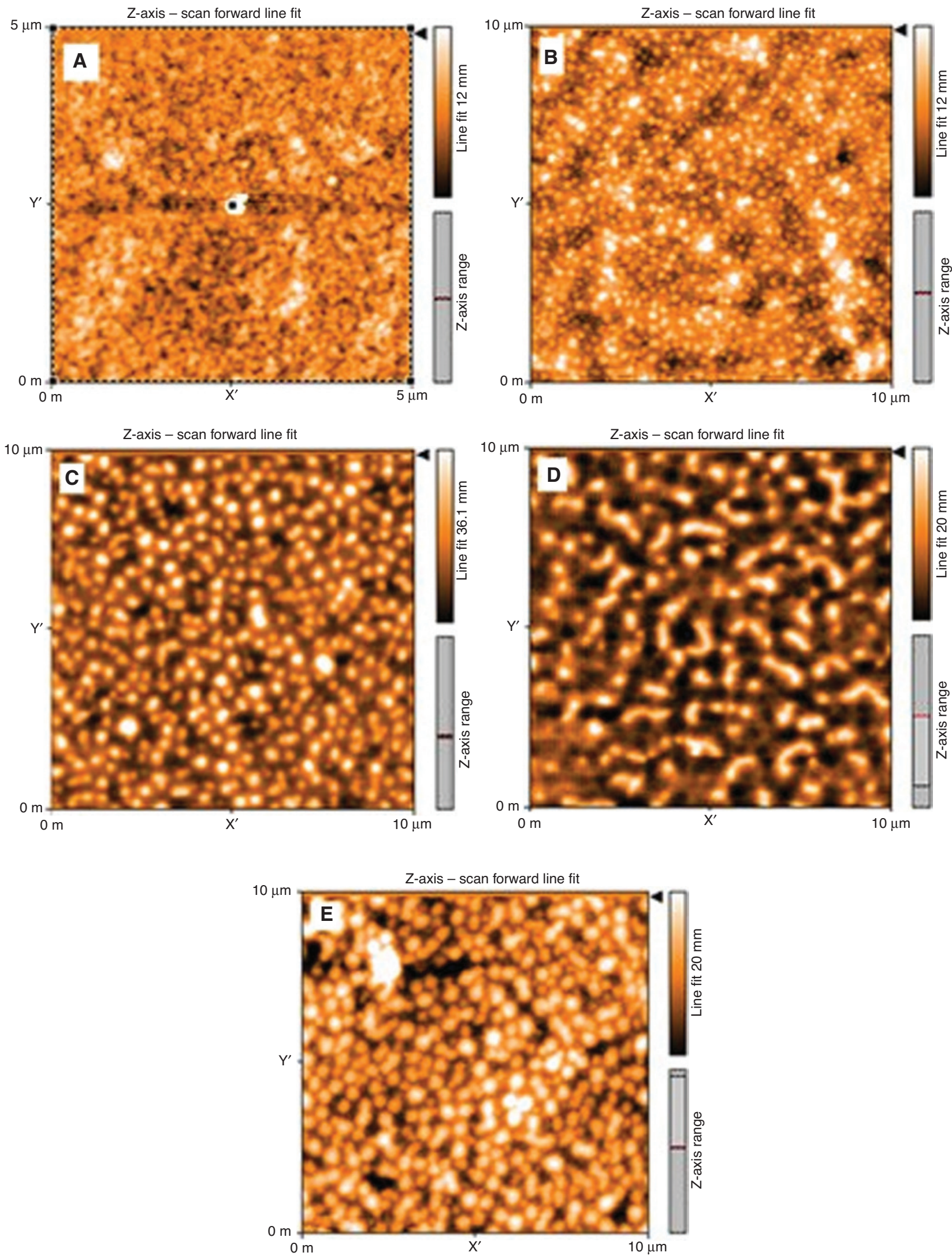

Figure 5: The AFM images of the (A) P3HT:PCBM, (B) Р3HT:PTB7:PCDTBT:PCBM, (C) P3HT:PTB7:PCBM, (D) P3HT:PCDTBT:PCBM, and (E) PTB7:PCDTBT:PCBM layers. 
for photoactive layers of P3HT:PTB7:PCBM and PTB7:PCDTBT:PCBM. Solar cells using PTB7 and PCDTBT polymers had rougher surfaces compared to the reference cell using P3HT. Use of low bandgap polymers obviously improved the $I_{\mathrm{sc}}$, and when combined with P3HT, higher $V_{\text {oc }}$ was enhanced, too. However, the fill factor, which gives information about the quality of solar cells, was worsened by the use of low band gap polymers in organic solar cells, and thus, this situation resulted in lower PCE in P3HT:PTB7:PCDTBT:PCBM, P3HT:PTB7:PCBM, P3HT:PCDTBT:PCBM, and PTB7:PCDTBT:PCBM. These findings will help to understand the properties and behavior of semiconducting polymers with different bandgaps in organic solar cells for further studies.

Acknowledgments: This study was supported by Turkish Scientific and Technical Research Council, TUBITAK, project no: 113M950. Suleyman Gungor is also acknowledged for helping with the experiments in the laboratory.

\section{References}

[1] Yu G, Gao J, Hummelen JC, Wudl F, Heeger AJ. Science 1995, 270, 1789-1791.

[2] Photovoltaics Report. Fraunhofer Institute for Solar Energy Systems, 2018.

[3] Spanggaard H, Krebs FC. Sol. Energy Mater. Sol. Cells 2004, $83,125-146$.

[4] Brabec CJ, Sariciftci NS, Hummelen JC. Adv. Funct. Mater. 2001, $11,15-26$.

[5] Nunzi JM. C. R. Phys. 2002, 3, 523-542.

[6] Hoppe H, Sariciftci NS. J. Mater. Chem. 2006, 16, 45-61.

[7] Bedeloglu A, Demir A, Bozkurt Y, Sariciftci NS. Renew. Energ. 2010, 35, 2301-2306.

[8] Cao WR, Li ZF, Yang YX, Zheng Y, Yu WJ, Afzal R, Xue JG. Renew. Energ. 2014, 72, 134-139.

[9] Liu C, Wang K, Gong X, Heeger AJ. Chem. Soc. Rev. 2016, 45, 4848-4849.

[10] Krebs FC. Sol. Energy Mater. Sol. Cells 2007, 91, 953.

[11] Dennler G, Scharber MC, Brabec CJ. Adv. Mate. 2009, 21, 1323-1338.

[12] Gendron D, Leclerc M. Energ. Environ. Sci. 2011, 4, 1225-1237.

[13] Hou JH, Chen HY, Zhang SQ, Chen RI, Yang Y, Wu Y, Li G. J. Am. Chem. Soc. 2009, 131, 15586.

[14] Peng Q, Liu XJ, Su D, Fu GW, Xu J, Dai LM. Adv. Mater. 2011, 23, 4554-4558.
[15] Price SC, Stuart AC, Yang LQ, Zhou HX, You W. J. Am. Chem. Soc. 2011, 133, 4625-4631.

[16] Chu TY, Lu JP, Beaupre S, Zhang YG, Pouliot JR, Wakim S, Zhou JY, Leclerc M, Li Z, Ding JF, Tao Y. J. Am. Chem. Soc. 2011, 133, 4250-4253.

[17] Dou LT, You JB, Yang J, Chen CC, He YJ, Murase S, Moriarty T, Emery K, Li G, Yang Y. Nat. Photonics 2012, 6, 180-185.

[18] Small CE, Chen S, Subbiah J, Amb CM, Tsang SW, Lai TH, Reynolds JR, So F. Nat. Photonics 2012, 6, 115-120.

[19] He ZC, Xiao B, Liu F, Wu HB, Yang YL, Xiao S, Wang C, Russell TP, Cao Y. Nat. Photonics 2015, 9, 174-179.

[20] Rafat NH, Haleem AMA, Habib SED. Renew. Energ. 2007, 32, 21-34.

[21] Wang WP, Zhao BF, Wu HM, Guo ZQ, Mi YH, Zhang ZP, Gao C, An ZW. Synthetic Met. 2015, 206, 66-71.

[22] Jeong I, Kim J, Kim J, Lee J, Lee DY, Kim I, Park SH, Suh H. Synthetic Met. 2016, 213, 25-33.

[23] Zeng XH, Li ZF, Ren JK, Ge TX, Zang ZM, Sun QJ, Wang H, Hao YY. Synthetic Met. 2018, 240, 30-36.

[24] Sun JY, Venkatesan S, Dubey A, Qiao QQ, Zhang C. J. Polym. Sci. A1. 2017, 55, 1077-1085.

[25] Venkatesan S, Chen JH, Ngo EC, Dubey A, Khatiwada D, Zhang C, Qiao QQ. Nano Energy 2015, 12, 457-467.

[26] Xu B, Sai-Anand G, Gopalan Al, Qiao QQ, Kang SW. Polymers 2018, 10, 121

[27] Mohammad L, Chen QL, Mitul A, Sun JY, Khatiwada D, Vaagensmith B, Zhang C, Li J, Qiao QQ. J. Phys. Chem. C. 2015, 119, 18992-19000.

[28] Sai-Anand G, Dubey A, Gopalan Al, Venkatesan S, Ruban S, Reza KM, Choi J, Lakhi KS, Xu BR, Qiao QQ, Vinu A. Sol. Energy Mater. Sol. Cells 2018, 182, 246-254.

[29] Huang D, Xu Z, Zhao SL, Li Y, Zhao L, Jin SQ. Appl. Surf. Sci. 2015, 353, 1253-1259.

[30] Gunes S, Neugebauer H, Sariciftci NS. Chem. Rev. 2007, 107, 1324-1338.

[31] Supriyanto A, Mustaqim A, Agustin M, Ramelan AH, Suyitno, Rosa ES, Yofentina, Nurosyid F. IOP Conference Series: Materials Science and Engineering. 2016, 107, 012050.

[32] Borchert H, SpringerLink (Online service). Solar Cells Based on Colloidal Nanocrystals, Springer Series in Materials Science, Springer International Publishing: Imprint: Springer, Cham, 2014.

[33] Hoefler SF, Rath T, Pastukhova N, Pavlica E, Scheunemann D, Wilken S, Kunert B, Resel R, Hobisch M, Xiao S, Bratina G, Trimmel G. J. Mater. Chem. A. 2018, 6, 9506-9516.

[34] Cai WZ, Zhong CM, Duan CH, Hu ZC, Dong S, Cao DR, Lei M, Huang F, Cao Y. Appl. Phys. Lett. 2015, 106, 233302.

[35] Ergete A, Sabir FK, Li Y, Yohannes T. J. Photon. Energy 2015, 5, Article No. 057209.

[36] Goh T, Huang J-S, Bartolome B, Sfeir MY, Vaisman M, Lee ML, Taylor AD. J. Mater. Chem. A. 2015, 3, 18611-18621.

[37] Ebenhoch B, Thomson SAJ, Genevičius K, Juška G, Samuel IDW. Org. Electron. 2015, 22, 62-68. 